\title{
STATE CRIMES IN THE ILC DRAFT ARTICLES ON STATE RESPONSIBILITY: INSIGHTS FROM MUNICIPAL EXPERIENCE WITH CORPORATE CRIMES
}

\author{
by David D. Caron*
}

If the twentieth century has been the century of codification for international law, then the broad area of state responsibility is the last area awaiting such a transformation. My task is to address the provisions of the International Law Commission (ILC) Draft Articles on State Responsibility that set forth and address the notion of state crimes.

As Professor Crawford stated, state crimes undoubtedly constitute one of the most controversial aspects of the Draft Articles. The Summary Records of the ILC Reports dealing with state responsibility over the past twenty-five years confirm Professor Crawford's remark that the ILC's development of the state crime idea is discombobulated. Particularly difficult for the ILC was the fact that its consideration of the subject extended piecemeal over such a long period. When the notion of state crimes was adopted, the ILC did not yet know what the consequences of making a distinction between crimes and delicts would be. When the Commission years later reached the subject of such consequences, the fact that state crimes were already a part of earlier draft articles tended toward its retention and continued elaboration.

States, in contrast to the ILC, feel no such commitment to the notion of state crimes, and thus far their comments have been quite critical of the notion. States argue that (1) the notion of state crimes is unsupported by practice, (2) the endorsement of criminal prosecution of the state will undermine the movement to prosecute the responsible individuals, and (3) the notion of state crimes does not add anything to the combination of ordinary state responsibility and jus cogens norms. In addition, many specific criticisms, by no means unimportant, go to drafting. Some states, for example, argue that the draft provisions are exceedingly vague and note that many municipal systems would hold such vagueness to be a bar to enforceability of such norms. Although states, in such comments, are developing the outline of the debate to come, the comments thus far are also rather repetitive and preliminary. Thus, rather than exploring those comments and related academic literature in this presentation, I instead seek to bring to bear on this emerging debate the extensive consideration that has been given to corporate crimes in various national systems. ${ }^{1}$

A number of states argue that the notion of state crimes is simply unsupported by practice, and they might further contend that the practice within states regarding corporate crimes is simply irrelevant. Although some states go too far in stating that there is "no" practice supporting the idea of state crimes, it is true that the practice is limited. But how much force should be given to this observation in any event? Even if one were to conclude that the notion of a state crime does not exist as of yet and that the ILC is thus progressively developing, rather than codifying, the law of state responsibility in this regard, that conclusion does not preclude the further conclusion that the notion of state crimes is a desirable element in the law of state responsibility. As a U.S. delegate has said, "Other provisions .... went far beyond current law and practice. Sweeping . . . provisions imprecisely formulated and defined, were potentially very damaging in the light of the failure of the Draft Articles to provide adequate safeguards." What is interesting about this

'C. William Maxeiner Distinguished Professor of Law, School of Law, University of California at Berkeley. I wish to thank Ms. Ceide Zapparoni, LL.M. Candidate, School of Law, University of California at Berkeley, for her able research assistance.

'When referring to corporate and state crimes collectively, I will use the term organizational crimes. 
statement is that it is not from a U.S. representative discussing the State Responsibility Draft Articles and the notion of state crimes in 1998, but rather from one discussing the Draft Articles on the Law of Treaties and the notion of jus cogens in $1967 .^{2}$ To point out that state crimes are new advises cautious assessment of their merit, but is not in itself a bar to their adoption.

Thus, prescriptively, the practice and literature to consider is not only that in international law, but also the experience of many nations and the writings of many scholars concerning corporate crimes. It is particularly relevant to do so because corporate crimes not only exist in much of the common-law world but are also finding a place in civil-law Europe. Moreover, it is likely that this national experience with corporate crime has influenced, at least indirectly, the attitudes of states and nongovernmental organizations (NGOs) supporting or opposing the relevant articles of the ILC Draft. Indeed, the ILC Summary Report for 1995 suggests that unspecified analogies to corporate crimes were made.

A review of this municipal experience with corporate crimes, particularly in the United States, leads me to make three points. In drawing these lessons, as is always the case with comparative exercises, I have attempted to exercise great care in drawing analogies between municipal practice and international interstate practice. ${ }^{3}$

But before laying out these points, I emphasize that the examination of the national corporate crime experience is complicated by the fact that it exhibits considerable variation even within a single state. Although other jurisdictions were examined, my comments relate primarily to the United States, where corporate criminal responsibility has been quite popular since the Supreme Court, in New York Central \& Hudson River Railroad v. United States, 212 U.S. 481, 493 (1909), decided that a corporation could be as liable for the acts of its employees under the criminal law as under the civil law, under the doctrine of respondeat superior, on unspecified "policy grounds." In that case, the Supreme Court dismissed the argument that innocent shareholders would suffer. The Court said that the great majority of business transactions were made through corporations, and acts of a corporation's agent could be controlled by imputing liability to his employer "on public policy grounds." But since then, in the view of Daniel R. Fischel and Alan O. Sykes, the "doctrine of corporate criminal liability has developed [in the United States] ... without any theoretical justification." ${ }^{4}$ Likewise, the Model Penal Code states that the development of corporate criminal responsibility has proceeded without reference to "any intelligible body of principle" and in the absence of "articulate analysis." An explanation for such incoherence in the field is that in each state such crimes are set forth in individual statutes-an invitation to experimentation.

\section{The Arguments for Corporate Crimes and the Value of Moral Stigma}

In the justifications of corporate crimes and state crimes, the question that always arises is: What does a regime of organizational criminal responsibility add to the already existing regimes of organizational civil responsibility and individual criminal and civil responsibility?

The primary justifications asserted for corporate criminal responsibility are threefold. First, the imposition of fines will increase deterrence. Second, the stigma (or "reputational damages") of being found criminally responsible will increase deterrence. Third, such criminal responsibility satisfies a public societal need for retribution against a perceived bad

${ }^{2}$ U.S. PARTICIPATION IN THE UN: REPORT BY THE PRESIDENT TO THE CONGRESS 239-40 (1969).

${ }^{3}$ In the 1995 Summary Record of the ILC's 47th Session, one member is reported as having said that an unspecified analogy to corporate crimes was "extremely tenuous."

${ }^{4}$ Daniel R. Fischel \& Alan O. Sykes, Corporate Crime, 25 J. LEGAL STUd. 319 (1996).

${ }^{5}$ MODEL PENAL CODE AND COMMENTARIES art. 2.07, § 332 (1985). 
actor. All of these arguments likewise have been made in support of the criminal responsibility of states.

Underlying these justifications is the assumption or conclusion that criminal proceedings will yield these particular desirable results, while the other regimes of individual criminality and organizational civil responsibility will not. From this perspective, it seems clear that organizational criminal proceedings supply a moral stigma that the other regimes do not. John C. Coffee, Jr., writes that "[t] he classic reason offered for using the criminal law when financially equivalent civil remedies are available has been that the criminal law uniquely can focus public censure upon the guilty defendant." In Coffee's words, the criminal law possesses a "[u]nique moral force."7 There may be quite tangible consequences to such moral stigma. A corporate attorney argues, for example, that the stigma of a criminal prosecution can have effect on the long-term profitability of a corporation through an increase in the risk of investment in that corporation. ${ }^{8}$ One can imagine similar conclusions being reached with regard to states and the risk associated with investment in such states.

It is far less clear that the fines that accompany a criminal prosecution accomplish something more than civil penalties do. From an economic perspective, deterrence-at least as a result of a fine or penalty - takes place when the "expected punishment cost" of the proscribed action exceeds the expected gain, as discounted by the likelihood of apprehension and conviction. The imposition of criminal liability thus potentially provides the firm with the correct incentives to invest in cost-justified precautions-for example, monitoring of employee activities-to prevent crimes from occurring. It is argued by some that such deterrence is appropriate inasmuch as the corporation, after all, is in a better position than the government to detect and punish misconduct by its employees. Similarly, it can be argued in the international case that the state is in a better position than the amorphous international community to monitor and punish its agents.

But this model of incentives and rational actors would seem equally satisfied with ordinary civil, rather than criminal, state responsibility, unless the civil penalty is limited to an amount significantly less than the criminal fine. Moreover, one must question the use of such a model with states in any event, since the dearth of compulsory international adjudicative institutions would suggest that states would significantly discount the punishment cost, given the low likelihood of apprehension and conviction.

The important point, therefore, is that the primary justification for the notion of state crimes is the moral stigma of criminal conviction. But if that is the case, then the infamous footnote to Article 40 of the ILC Draft Articles, mentioned by Professor Crawford, is of crucial significance. If the answer to objections to the Draft Articles is to change the name of this category of norms so as to reduce the penal character of the category, then the primary reason for the category at all is undermined, if not eliminated. The main value of the notion of state crimes is the word crime. If the moral force of this word is removed, then the game may not be worth the candle.

The Arguments against Corporate Crimes and the Question of Whether Innocents Suffer

The number of arguments raised against corporate crimes is considerably greater than the number of justifications, although one should keep in mind that many of the arguments

'John C. Coffee, Jr., 'No Soul to Damn: No Body to Kick': An Unscandalized Inquiry into the Problem of Corporate Punishment, 79 MiCH. L. REv. 386, 447 (1981).

${ }^{7}$ John C. Coffee, Jr., Paradigms Lost: The Blurring of the Criminal and Civil Law Models-And What Can Be Done About It, 101 Yale L.J. 1875 (1992).

${ }^{8}$ Carol L. Bros, A Fresh Assault on the Hazardous Workplace: Corporate Homicide Liability for Workplace Fatalities in Minnesota, 15 WM. MITCHELL L. REV. 287 (1989). 
apply to only certain forms of corporate crimes. Before focusing on the morally central argument that innocents suffer, I will briefly touch on a few of the other arguments.

First, a number of commentators suggest that all realistic and proper aims of corporate criminal liability are served by imposition of civil responsibility. ${ }^{9}$ This argument is likewise made with regard to state crimes.

Second, others question whether this use of the "unique moral force" of criminal law is destructive of that unique force. Professor Coffee argues that there has been a trend toward encroachment of the criminal law into areas formerly thought of as civil or regulatory in character, and that this should be resisted. Overuse of the criminal law, in his view, impairs its role of "moral education."

Third, criminal proceedings are more expensive. In the municipal context, it has been argued that there are greater costs associated with criminal proceedings, largely because of greater procedural protections. Evidence must be "beyond reasonable doubt." This requires greater resources in terms of evidence gathering and presentation than the "preponderance of the evidence" standard. In addition, accused have greater rights to procedural protections, which leads to more expensive trials. It is somewhat unclear whether, in the international context, such criminal procedural protections and higher evidentiary standards would apply. But I would think it likely that the greater moral force that is sought to be wielded by this form of criminal proceedings logically would give rise to increases in evidentiary burden and procedural protections. Such features of the criminal trial could not be substantially relaxed without undermining the perceived legitimacy of the result.

Fourth, deterrence in fact may not be enhanced. Professor Coffee asserts that fines on corporations have been inadequate at achieving deterrence. Certainly if the fine is set too low, the corporation may disregard the deterrence signal sent. But Professor Coffee refers also to the so-called deterrence trap whereby the maximum meaningful fine levied against a corporation is necessarily bounded by the wealth of the corporation, while the benefit to be gained is not limited in this way. ${ }^{1}$ Finally, in this framework, deterrence is unlikely when there are no set levels of fines because calculation is necessary for rational actors.

Fifth, corporate criminality may lead to fewer prosecutions of criminally responsible individuals. The views and evidence here, as best I can ascertain in this brief review, are conflicting and complicated. It also seems difficult to transfer these views to the international sphere, where the gravity of the crimes and the availability of enforcement mechanisms are so different. It is contended by some that there is a predisposition of juries to let individuals "off" yet punish the corporation on the same evidence. Yet, Coffee identifies what he calls the "nullification problem," that is, a reluctance among judges and juries to impose severe penalties on corporations. The international context may be critically different, in that the wronged state is potentially both the claimant in terms of the delict and the de facto prosecutor in terms of crimes. In the domestic context, the victim is the claimant and the state is the prosecutor. The merger of roles in the international context may lead to more strategic choices on the part of the victim, yet these roles may come in time to separate as further institutions emerge on the international level. Is it more effective to pursue the individual rather than the organization? What is the stigmatizing effect of criminal proceedings on a corporation? Professor Coffee, in particular, concludes in the corporate context that a "dual focus" on corporation and individual is advisable."

${ }^{9}$ See, e.g., V.S. Khanna, Corporate Criminal Liability: What Purpose Does It Serve?, 109 HARV. L. REV. 1477 (1996).

${ }^{10}$ Coffee, supra note 7 , at 1877.

"Coffee, supra note 6, at 389-93.

${ }^{12} I d$. at 410. 
All of these arguments deserve close consideration, but I find the discussion concerning the moral position regarding innocents to be particularly important when considering the applicability of municipal corporate crime experience to state crimes.

Commentators point out that punishment imposes an external cost, that is, the costs of fines spill over onto "innocent" parties. The corporation does not bear the ultimate cost of a fine: "When the corporation catches a cold, someone else sneezes." Stockholders are frequently given this as an example. How is a state different from a corporation in this regard? In the international case, the innocents presumably are the citizens, and also corporations operating in the relevant state, both of which could suffer the burden in increased taxes and a lower quality of life, or the higher costs of doing business, because of instability. The primary parallel is that the citizen is to the state as the shareholder is to the corporation.

In the case of corporations, the justification for the suffering of the shareholders is that such shareholders were unjustly enriched because of the crimes of the corporation, and, indeed, it is possible that it is this very profitability that led the shareholders to invest in the firm - they may disinvest, they may seek information about companies' practices. This justification does not work nearly as neatly in the case of states. Like the shareholders, some citizens of the state may be unjustly enriched by the crime of the state. But not all citizens are "shareholders" in the state. We also must bear in mind that citizens cannot exit the state as a shareholder may move between corporations. In addition, with corporations it is rare that the criminal statutes involve the commission of a crime against the corporation itself. But-and the list of state crimes proposed in the ILC Draft Articles reflect this-a state, without question, can commit a crime against its own people. In this circumstance, the citizen is not only not a shareholder, he or she is also the victim. Moreover, if the state is criminally fined, in all likelihood those victims become victims once again. But, then again, these last considerations apply as well to the civil responsibility of states.

\section{Due Diligence, Not Presently Provided for in the Draft Articles, Should Be a Means of Avoiding Criminality}

Criminal jurisprudence ties moral culpability to intent; crimes require both an act and a mens rea. But what then does it mean to speak of an organization being criminally responsible? Corporations and states do not have intent. One approach is to view organizational criminal culpability as rooted in the failure of the organization to structure itself so as to mimic the self-reflection of an individual. Thus, if a state establishes processes, issues guidelines and diligently seeks to control criminal behavior by its agents, then it should not be morally culpable if such an agent commits an act that otherwise would be a state crime. In other words, the criminal responsibility of corporations should be limited to cases in which there has been a failure to put systems in place designed to prevent the crime. The Draft Articles at present, however, do not provide that the exercise of due diligence, or indeed any other level of care, would be a means to avoid criminality. Scholarly commentary on corporate crime strongly supports the view that if an organization gives specific instructions to its agents and a rogue individual nonetheless violates such instructions, then the organization should be free of at least criminal responsibility for the acts of the individual. This reasoning should be extended to states and the Draft Articles. If so, this in turn suggests that the rules of attribution or circumstances precluding wrongfulness would need to be revisited so that they would vary depending upon whether ordinary or criminal state responsibility was involved.

\section{Conclusion}

The notion of state crimes will face not only rigorous scrutiny (clearly justified given the present text of the Draft Articles) but also strong opposition (a position of which I am 
not yet convinced). Some argue that the state crimes provisions, unlike the rest of the Draft Articles, are substantive and therefore not properly a part of this attempt to codify the transubstantiating rules of state responsibility. This may be true of the particular Draft Article that attempts to list the crimes, but is not true to the extent that the rules of attribution, circumstances mitigating wrongfulness or remedies turn upon whether the act is viewed in terms of ordinary or criminal responsibility. Others will seek to carve the notion of state crimes out of the Draft Articles entirely and reserve it as a topic for further study by the ILC.

My brief review here of municipal experience thus far indicates that valuable insights can be found in the relatively developed debate surrounding that experience. My chief conclusion is that the addition of a "lack of due diligence" requirement as an element of a state crime is not only an appropriate change, but, more significantly, a necessary change if the notion of state crimes is to win wider acceptance by states. The requirement that the state fail to exercise due diligence may alleviate the fears of some states that they may be unjustly harassed by the specter of criminal charges. Simultaneously, such a change will allow the majority of states to focus on those very few states that either from the onset intentionally violate the central prohibitions of the modern world or that do not exercise the due diligence required of a modern state to prevent their agents from committing such acts. 